\title{
An Analysis of Useful Customary Practice in Hadiya Culture: The Case of "Landimacho"
}

\author{
Adane Woldeab Shanko \\ Lecturer and Researcher at Wachemo University, Ethiopia
}

\begin{abstract}
Developing and preserving the use of indigenous knowledge, skills and heritages can play an essential role in ensuring utility and sustainable transmission of cultural heritages for new generations. Therefore, the main purpose of this study was to investigate the role of indigenous institution (Landmacho) in settling conflicts in the Hadiya people in Hadiya Zone Southern Nations, Nationalities and Peoples Regional State (SNNPRS) of Ethiopia. Qualitative research design was employed in the study for its appropriateness to assess the role of indigenous institutions in resolution of conflicts in the study area and Purposive sampling technique was employed to select the interviewee in the data collection. Landimacho is the truth of women and is the ruling system in the Hadiya society that is given to females or women only. It is culturally persuading system of two or more group of people's conflict in the Hadiya society. The conflict is reached high point and male counterpart tried to solve but they cannot solve it. So, it is forced to be given to women of the society. It has a great role in conflict resolution, crime investigation and peacemaking in the society. To keep this value of society awareness creation, trainings about women's role to the society, educating women to flourish it, increasing women's participation and are mentioned to be the main recommendations to present a good attitude towards function of landimacho in the society.
\end{abstract}

Keywords: indigenous, guff-guddima, xiigguulla, landimacho, geja, Wogana.

DOI: $10.7176 /$ JLLL/72-01

Publication date:October $31^{\text {st }} 2020$

\section{Introduction}

Hadiyya is a Zone in the Ethiopian Southern Nations, Nationalities and Peoples Region (SNNPR) of Ethiopia. The Hadiyya people have their own historical origin and development. The historical background of Hadiyya has been studied by various scholars, e.g. Braukämper (2004), Haile (1973), and Lapiso (1982). Alebachew and Samuel (2002), who give a detailed account of the political and socio-cultural history of the Hadiyya people cited in Tadesse Sibamo, 2014.

Hadiya is a nation with listless number of very important social, cultural, political as well as religious practices which have been being practiced for centuries. However, almost all of these important indigenous practices have not yet been formally written and preserved in books, papers and journals. The essence and the procedures of all those practices are being disseminated from generation to generation through oral literatures. Thus, this is the right time to redeem these useful customary practices from being abolished.

The rich culture of the nation, more particularly the folklore type, the use of traditional arts and handcraft products in wider communities among young generations has become threatened because of swift socio-cultural changes as result of modernization.

Preserving these useful customary practices is inevitable for educators, researchers and other concerned bodies, and it would be indispensable to keep the identity of the members of the nation. The society uses these customary practices for different purposes. For example, to regulate the social conflicts that may rise in the society or reconciliation (xiigguulla); to resolution of conflict in women's position (landimacho); to share the personal burden of works in customary cooperatives work (geja) and to cattle counting and blessing ceremonies (wogana) etc.

According to Haile, 1973 in oral tradition of Hadiya, women position in different cultural values was great. In this culture, it is stated that what impresses Hadiya women about their husband is a strong character and heroism more than wealth.

Landimacho, one of the conflict settling or handling system which is type of folklore grouped under social folk costumer practice is widely used in Hadiya people to reconcile conflict in the society. It is the most and last stage of conflict resolution method in Hadiya society. Its ceremony and structure is leaded seriously by elder women.

All these customary practices need to be documented so that it can be transferred from generation to generations. If we don't introduce and document these useful customary practices in time, the fate of these practices would be disappearance and it would be a difficult task to back up these disappearing customary practices.

\section{Objectives of the study}

The general objective of the study was to investigate landimacho which is cultural ceremony of Hadiya people. The specific objectives of the study were to: 
* Point out the way in which Hadiya society women problem solving system.

* Signpost how "landimachcho" program commemorate in the society by women.

* Designate the structure of landimacho ceremony of Hadiya people.

\section{Methodology}

This research was primarily a qualitative research design to analyze literary text. Multiple data sources were used to generate the required information to meet the research objectives, which includes primary \& secondary data sources. The primary data sources were interviews and focus group discussions whereas the secondary sources of data were journals, books, magazines, and other written documents. The data for analysis was randomly selected from oral love poems in Hadiyyisa.

The data for the study was gathered by using unstructured interview, focus group discussion, participatory observation \& document analysis of data collection method.

This study was done in two stages: The first phase was pilot survey. In the pilot survey, data collector undertakes this stage to familiarize with the respondents and the areas of study. It also helps to survey the kind of data will expect to collect. This helps to decide on the number of respondents the person will use in the main field program. Therefore, the pilot survey enables the members to improve on the methodology during the main field work.

The second phase was the main field work. The main fieldwork undertaken in twelve woredas of the Hadiya Zone namely; Duna, Anlemo, Sooro, Misha, Lemmo, Mesirak Badawacho, Hossana town, Mirab Badawacho, Shashogo, Gibe, Mirab Sooro and Gombora woredas.

The type of data was decided the type of the analysis that was followed. It means that since all the data collected was qualitative data, then it was analyzed qualitatively, using words to describe the data.

This article which narrates the customary practices was handled in two ways. One is recording the real practice while being practiced. The second one is recording the events being performed. The script of the data was written/narrated in two languages: Hadiya Language and English.

The first step in the analysis of data was jotted down the data from the interviewee. In the second stage, literal translation was carried out because the data was written in the Hadiya language. From the literal translation, actual or free translations were undertaken.

\section{Data Analysis and Interpretation}

This part discusses an analysis of data collected about landimacho from different sources and tools to mention interview, group discussion and participatory observation.

\section{A. Definition of "Landimacho"}

According to interview result the following data were discussed about the definition of landimacho: the first interviewee said that landimacho is the ruling system in the Hadiya society that is given to females or women only. It is culturally persuading or handling system of two or more group of people's conflict in the Hadiya society.

According to another interviewee, in Hadiya culture, landimacho process is done when two or more group of people's disagreements shall be occurred or/and one person or group harass or over act in other person or group can be resolving system in the society. They also point out that the word landimacho come from two umbrella terms i.e. 'landa' and 'machcho'. "Landa" has two meaning the first one is female sex indicator and the second meaning is that the generation creating or coming side (female). In other case "Machcho" is a material which produced from animals' skin and in the early period in the Hadiya culture, married women tied their waist to get strength or part of a cloth which is used to band waist. Symbolically, it represents to strengthening their clans. However, the most serious conflicts which are resolved in the lamdimacho ceremony are beating a man with a slump and/or thin stick, beating elderly, raping, murder, physical damage, insulting, adultery and so on.

\section{The Hadiyyisa version is listed in the following text.}

Land machchi bikkina annanni annanni uulli lomanni uwwamukki sawwixxisanne "Land machchi seer" Hadiyyi minaadab landina uwwoo daanoomiinse mato ihaa, Hadiyy landi wocammu manna Lommananno ammadaa iittansimma (iittansoo) heechchi qaanqaam seera yamaakko.

"Land machcho"yimmi Hadiyyi heechchi qaanqanne Hadiyy minaadab ixxi woronne qooccamoo aagixxanchcha hooggimmammi ihukko keemaa'l daamihiga te'im hawwo tirimina awaaxxakkam heechchi qaanqaam lomananno yoo sawwite uwwamaakko. Ka sawwitenne edamma land machcha yoo sagara lammaqqisagara ihaa ookkim"Landa" yoohannnee "machcho"yoohanne. Landaa yookkokki matisinne meenti allibachcha moo'isoohanne ihaa,mullisinne odim landi kollinne waaroo shumo'i qaroommma moo'isookko. "Machcho" odim gaassi doolle mine issu land lammado lade'oo ommachinne baxxamoo sabata yamaakko. Sabatta kukim bikkookok qarancha (moollo) qoxxisimma moo'isookko. Ku seerimmi moo'isookkok Hadiyyi landi mine issaa lasage landi qarammukki moollonne te'im maa'l qaronne duumaa duunchcha affisimma, maase'a odim maasso affisimmi daanooma ihaa, Ka daanooma baxxonne hosissimma xanookkok qarammukki moolli xalle'ennette yoo sawwite uwwamaakko. 
In general, landimacho is/was problem handling or settling system in Hadiya culture and everybody of the society is highly respecting it and its ceremony. The conflict is reached peak or climax point and male counterpart tried to solve but they cannot solve it. So, it is given to women of the society.

\section{B. Function of Landimacho}

In Hadiya culture, landimacho played a great role in conflict resolution. The society gives value and keeps it with fear it and its ceremony. Different elders of the society tell us its structure and function. It is comic and myth in nature. The respondents said that landimacho in Hadiya culture is an institution of women's conflict resolution system in the given position of the society and it comes from classical age i.e. from creation of human being in this world. The conflict type is highest and no one solve it other than women/females.

As the elders stated when a female heard the conflict of her society directly or indirectly from anybody, she told to both sides of the society elder women and they came from both side. They talked about the issue informally and every member of the ceremony begged leaving the tie of her waist-band. Then, no one oppose her idea and everybody accept her idea because if somebody oppose or disagree with her idea, she will curse the clan.

They communicate to each other and try to get solution and they agreed to make peace on both sides of the clan. Therefore, landimacho has such kind of great function in the Hadiya society.

The respondents also add another idea about landimacho function i.e. when the crime is hidden and they want to know that hidden crime source, they used landimacho technique. Such kind of crime investigation system in Ethiopia context is said to be afarsata.

Not only this but also landa/female's solve the curse that comes from forefather. When one group or clan may be cursed by the forefather and this curse may come across from generation to generation. Then, it can be solved by females. They can dig out it and bless by calling the name of elders and the man or woman who curse the generation. So, it has such kind of function in the Hadiya society.

In general, landimacho has different function in this culture. Some of general functions are/were conflict resolution, crime investigation and peacemaking in the society. Here is the original Hadiyyisa version.

Land machchi Hadiyyi heechchi qaanqanne qoccamu te'im keemaalisa wocamu manna land uwwakko'i danooma awwaaxxa iittaasiminnaa kee'maal woci qooccamoohare araasiminna awwadookkoo seer ihukkisa xamb bu'o uwwu Imanni caakkisamakko. Ixxuwwi caakkisamukkisinne ayyi manchim wocaamoo lambe'enne,ee moolli landichcho Land machchonne "magano" yita'a machcho titta'a unxxitolas ayyi manchchim landicho wosha sabaa qoccanchanne aagoyyo. Machchammo unixxito'ookko yakka'a malo hasimanne aaggakkamo. Eebikkinna Land machchi manni lambe'enne xumma qoocciminna araqa awwaadoohanne yoo sawwite uwwamaakko. "Land machchi" minaadaaphphi lambe'enne kee'maal hawwi qooccamoobee'isa, iittii hee'oo'isinnaa kee'maal maxxammu woshshi hee'oo ammane ee wosha qooccu manna la'iminnaa araqqa awwaadoohanne. Ixxuwwi yammukkisanne mat moolonne ayyi baxuda'e la'akko bee'i dammigi qooccamoo ammanne landina lommananno uwwakka'a ka jora baxu mannichchi ixxi anginne biiraa yaa waaro'isa xa'makkamo,ee ammane jora baxukki kolli biiraa yaa waarookko eebikkina land machchi araq awwaadoo heechchi qaanqaam seeraa yamaakko.

Mulli sawwite uwwamu mannisanne odim land machi mati moolli lambe'enne landichchi duunita'a gassito'i duunchi hee'oo ammane ee duunchcha fissimiinna awwaadoohane. Mat moolli woronne lanidicho mat mashka'inne duunta'a duuncha gassitenna xantammo. Ee garu duuncha isse foorine hee'lo'i lassi iss gogami ,issi leto'oolas issi shomo'i yoo landi maase'aa ee garu duuncha fissimminna landi machchi seeri araqqa awwaadoohanne yoo sawwite uwamaakko .

Hanaan landi machi see'l awwaaxxi bikina daayyamaninna hincukk sagal xa'mo'inna dayyamaanni uwwaamu sawwixxissinne laleme'i kitaabise siidamukki baa'yaaxxisinne land machchi seeri Hadiyyi ixxuwwi lambe'nne qooccamoo qoccancha tiriminna maxamaakko dammiqqi hawwo biira'issakka'a tiriminna mat moolli woronne landicho duunitaa gassito'i duunichcha fissimminna, iitto qoocciminna, ki'ookki qoccaanchi kee'maal gaabaanne affobee'isa mallo hassimminnnaa xumma qoocciminnaa araqa awwaadohanne ihukkisa saarayaanchi qoossaakko.

\section{Structural Organization of Landimacho}

Landimacho has its own structure and organization in the Hadiya culture. Fulfilling this structure and organization is mandatory unless it missed blessing value. Every participant should follow the procedure and come up with cultural materials which come to gather within the ceremony. The following Hadiyyisa version shows the structure of landimacho:

\section{(Landi Machchi See'l Illagi Lassagooma)}

Hadiyyi heechchi qaanqanne woccamu manna landi machchi lommannaninne iittansakeena hassakolas, hawwo tireena xanookko yakkam landina woshshi afoo'isa isssakkammo. Ka wosha macceesukki landi waaraa lommannano ammadookko.Landi machchi lommannonina ayyi manchim ijaajimim irito te'im giddo mashka'im land machchi lommannanina ijjammubee'las landi duumichinne beyyi bi'ookko yakkam ammanneti yoo bikkinatte. Landi machchi lommannan asheerrookkokk,woccanto'i lammem kollim hafi yookki haraar nafaranne/biirannel wi'xaa dummoo'is issimminete.Humdem ee moolli landim lamado 
machchinne ganqqa'aa lade'aa anganne karamaakoo sadda ammadookko. Duummichchaane giichchina caakkaa la'ammu bee'i luwwinne woccamaakkoo manni hee'ulas, landi «ka jora baxxu manchi moolo,sullo,waataa niinaa giichchinaa biira yihe»yaa ijaajookko. Ka jora baxukki kollim biiraa yaa landi illage hinculas iittansakkonna gudaakkoo yimma. Ee lasage landi hundim uullookko. Woccamukki lamem kollim sulli daannuwwi, giichchi lommani landinse affaree'n kollinne uulookko; bi'ishsha ammanukki kolli landi illagenne guruphphookko; oohim «bi'insaamo haafi yilehe» yimmamoo'isoohanne. Landmachcho, tiraa, sulli, giichchimii, neesemi, ammadamu, luwwa, fatakkinaamo fatakkamoonna!» yookko. Lasaanchchone duummichchi, daba'laa, hafane, afuurookko.

Hawwodamukku kolli hawwodukki kolli haaf yoo'isa issakkamo. Ee lasage, sas landi doo'lamaa sas gabatanne te'im gabeen made'uwwanne gudaakko diinqa xaliili buuroo wo'oo ammadaa uulookko; gatukki landim karaa anganne ammadukki sadda tiraa uulookko.Gabatta ammadukki landi woriinse diinqa ammado'otte ammado'i sadda diinqanne ceeffa'a iittamukki manni hanenne kifu'uuyya," mati matina ka diinqisa xeelehe!'Yitamo. Buuli xaliili ammado'otem sadda buu'l xallillanne ceeffa'a hanenne kiffu'uyya, «ka buu'l xallilisa liniitehe, li'ilehe,danehe!» yitamo. Ee'isam wo'oo ammado'otem sadda wo'onne ceeffa'a hanene kiffu'uuyya, «woccancha sigginsaammo siigoona,gome'e gonsaamo bi'onna, wollabaninnee haydaqqanchchinnee hee'lehe!» yitamo. Mulli landim lasonn aaga maase'okko. Ee iittaansukki landi giichchi lommanni sulli dannuwwii dabaraa; «ni nafara xummissakko'ookko kinnuwwi mine xummi aagona, gattakko'i nafarane hibbanitakka'a,haydantakka'a hee'lehe " yaa massee'okko.Iittamu manni masse'ukki landikaa guddummo,goo'nekkaa te'im dummu mannikka anga afuuru beyyonne doo'aamukkuuyya suunqqamookko.Ittanisukki landim guddisakko'i edechcha edeesakkamo,iittansu landi annichchi annichchinam gudu luwwa itammaatii aggamaatii lasage landina laboo luwwa uwwaka'a geegeessakkammo. Lule'omannemi Hadiyyi heechchi qaanqanne landi machchi daanoom hibbamaakkohanne;landa badoo bee'i molli, daann, giichchi, lommanichchi lakki, ldilii hee'ooyyo. Landi machchi daanoominna te'im lommannaninna giichchi hundim ijaajjamimmi kabalam yohanne ihu kkisaa soroobaanchi la'aakko.

Chronological order/Steps of Land Macho Ceremony

The steps of landimacho ceremony in Hadiya culture have its own procedures. The above Hadiyyisa version is summarized in the following ways. The procedures are most probably accepted steps in Hadiya culture: first, informing the issue to all belonging women by leader or who can communicate with two groups $\rightarrow$ the women come and get together all about landimacho program $\rightarrow$ the two groups come together and meet in wider area especially under the oak tree $\rightarrow$ all participants of landimacho program come to the meeting place within cultural materials such as grass, butter, cloth of waist-band and so on $\rightarrow$ the women's said those who do such a bad thing "tell us or say something about the issue" $\rightarrow$ all women stand up, the clans members stand up at back of the leaders of landmacho and the women those come from both sides of the society kneel down $\rightarrow$ women leave tied waistband cloth and the member of clans from the both sides said we forgive, we forgive them, all members forgive them said repeatedly $\rightarrow$ the side of those who do wrong thing standup in front of the clans member and kneel down $\rightarrow$ all members come together to the shadow of an oak tree and those who is wronged side said we forgive them and give blessing $\rightarrow$ after that three representative elder women should be selected and they come caught or grasped honey, butter and water and stand in front of members $\rightarrow$ the one who caught or grasped honey said be tasty like honey to each other; the one who caught or grasped butter said be purified, filtered like butter your heart and the one who caught or grasped water said be cool, cooled down and dropped off like water and wrong thing come out from your generation and blessed them $\rightarrow$ the blessed women, clans members and those who come to bless should eat, drink, and wear cultural cloth that ready to peace makers, reconciler, or mediator. Lastly, give respected gift to the women who come to the ceremony to make peace.

\section{Material culture that is used in the Landimacho ceremony}

The following materials are used in the landimacho ceremony and each of them has its own symbolic values in the society's culture.

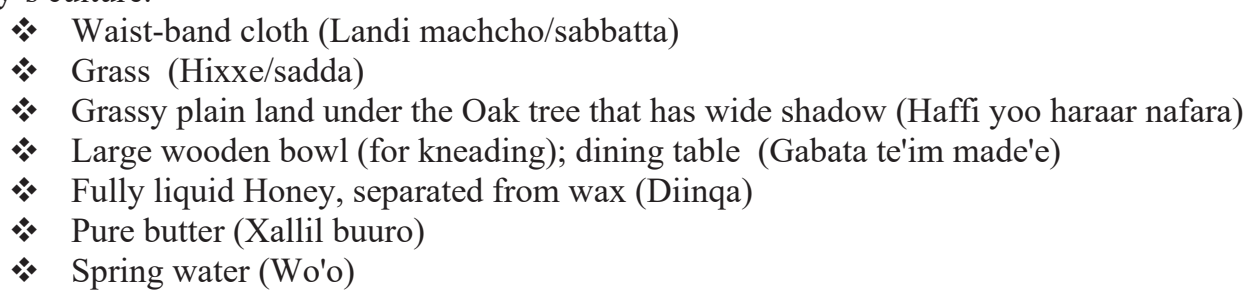

As my interviewee stated the above materials indicates many different symbolic expressions in the Hadiya culture. Waist-band cloth: when they leave tied waist-band cloth, it symbolizes they said we forgive you; in contrast when they don't leave waist band cloth, they don't forgive them and they curse as mentioned in the Holy Bible Deuteronomy 28:1.

Grass (a bunch of grass): - grass or a bunch of grass indicates promise, and the grass is tied in a bunch this 
symbolizes be united don't be departed or alone each other. A bunch symbolized unity.

Honey, filtered from wax: - this indicates that be sweet like honey one to other and love one another like the test of honey. Be pure like filtered honey from wax. Wax is bad sprit in the pure things.

Butter: - symbolize nothing is purely seen like butter so be pure like butter. The butter is filtered so be pure like this butter.

Water: - water makes things clean and purely seen when we see in the spring. Therefore, it symbolized the disagreement among you should be cool like water. It also symbolizes emancipation. So, you should be emancipated from sin or bad sprit.

Grassy plain land under the Oak tree that has wider shadow:-shadow symbolizes forgiving, protection from external thing and if you forgive to each other, you become widen like plain land and oak tree.

Large wooden bowl (for kneading); dining table: - wooden bowl symbolize that full thing and after blessing, everybody should be fulfilled within everything that is necessary to your life.

\section{E. Participants in the landimacho ceremony}

Girls/Women: girls from both sides of generation that better in age level and understanding capacity and expected that they can solve such kind of conflict easily. (In this study the word or the concept girl indicates all the women of that society who have given respect)

People that tried to persuade before that time: they also participate in the landimacho ceremony because they add information about the previous thing.

National peace maker old man: in the landimacho ceremony they have played a great role specifically they blessed peace maker girls or women and those who the issue concerning bodies.

Clan leaders: clan leaders and elders are participants of the ceremony and bless girls or women after ceremony.

\section{F. Oral literature used in the landimacho ceremony}

Oral literature cannot be studied and analyzed meaningfully outside the socio-cultural forces of the society that created it. This is because, like other vehicles of culture, they serve as carriers of a people's culture and history. Oral literature is a highly wide scope concept of any society's oral tradition. It plays a great role in society as either deductive or aesthetic function. Didactic function of oral literature imply the educative (pedagogic) functions through which express, promote and recognize the beliefs and customs; care for and reinforce morality and tradition by giving them higher value. Tadese's thesis (2004: 46) illustrated that "Thus, its art both material and moral, inspiration and frustration, customary practices, social norms, in short, the sum total of its realities of life can be observed and learned through oral literature. Therefore, in the landimacho ceremony oral literature is used as moral value that is to teach conduct of the society.

\section{$>$ Oral literature that reflect strength of landimacho}

\section{Jaaju'l Jeela}

Jaaju'l Jeela is a type of grass that grew after the curse of some family in Hadiya culture in general and in Jaajura in particular. Jaajura is a kebele which is found in Sooro woreda. Jaaju'l jeela is a type of historical curse that the woman who was found in Hadiya zone Sooro worada Jaajura kebele cursed that area. The woman is the lady who lived in her father land with her husband who came from other clan. When her child was looking after the cattle, the cattle ate growing seed of her family. The owner of seed killed the child. His mother cursed that society and they are cursed society for a long time. In the area jeela or unwanted grass grew but nothing else. The society said that area Jaaju'l jeela. After a long time later, the societies communicated about the issue and brought the ladies from that woman family and by landimacho ceremony bless that cursed family. Those who came that meeting place bless belonging bodies. Therefore, in landimacho process Jaaju'l jeela is the best oral literature used as an example to remind the bad effect of curse in every society and it is respected in every ceremony of landimacho.

\section{Adaayye's stick}

Jeelo is a lady, who was found in Buriyye, a village which is found in Hadiya Zone Sooro woreda Buriyye kebele. When she was coming to that village, two brothers were fighting each other. Jeelo came to them and said no one do this bad thing. Then, she leaves the symbolic stick in between the two brothers fighting place. The conflict became settled and she made peace. That stick is said to be Adaay losho'o (Adaayye's stick). That time onward in landimacho ceremony Adaayy losho'o is the best oral literature used as an example to remind the bad effect of the curse in every society of Hadiya.

Hanjo'o

Miroore is the son of Hade and Hanjo'o is the lady of Miroore who is found in Hadiya Zone Sooro woreda. Miroore and Buriye have spring water that is found at border of the two brothers. They were used this water to drink their cattle. Usually they make conflict in the water i.e. who drink the cattle first. This water made challenge day and night between the two brothers. After many challenges Hanjo'o cursed the water and the water disappeared. She made peace even though they lack spring water. This oral literature is used in Hadiya landimacho program as a warning weapon their families, society and clan. They also bless their children by calling the name Hanjo'o and Losho'o. Therefore, oral literature has such kind of strong effect in landimacho ceremony and other programs of the Hadiya society. 


\section{Conclusions \& Recommendations \\ 5.1 Conclusions}

In Hadiya culture, landimacho is given to Hadiya girls/women and used to conflict resolution system in the society. The word landimacho is an umbrella terms i.e. 'landa' and 'machcho'. "Landa" has two meanings the first one is female sex indicator and the second meaning is that the generation creating or coming side. In other way "Machcho" is a material which produced from animals' skin and in the early period in the Hadiya culture married women tied their waist to get strength or a cloth which is used to band waist. Symbolically, it represents to strengthening their clans. In general, landimacho is problem handling or settling system when the conflict is reached pick point and male counterpart tried to solve but they cannot solve it. So, it is forced to be given to women of the society.

Landimacho has different function in the Hadiya culture. It has great role in conflict resolution, crime investigation and peacemaking in the society.

It has also own structure and organization. Fulfilling this structure and organization is mandatory unless it missed blessing value. Every participant should follow the procedure and come up with cultural materials which come to gather within the ceremony.

In the landimacho ceremony some important materials are used and each of them has its own symbolic values in the society's culture. These are waist-band cloth, grass, grassy plain land under the Oak tree that has wide shadow, large wooden bowl; dining table, fully liquid Honey, separated from wax, pure butter and spring water. These materials have their own symbolic expression. Therefore, landimacho ceremony play a great role in the Hadiya society and every member of the society respect it.

\subsection{Recommendations}

Even though the landimacho ceremony plays a great role in the Hadiya society, it is not fully introduced in some part of the society and informed widely in the other society. The following recommendations were forwarded:

$>$ It should be extensively taught throughout the study area \& other places.

$>$ The society should also participate in the ceremony starting from early childhood.

$>$ Women should be openly discussed about their role \& they should be taught and encouraged to assertively practice it.

$>$ Elders in the society, who often participate in the lanndimacho ceremony are expected to consider the effect of the women often they understood the reality

$>$ Awareness creation, trainings about women's role to the society, educating women, increasing women's participation.

Therefore, the concerned bodies like government, society, and Non-governmental Originations (NGOs) should facilitate this action of women to overcome.

\section{References}

Abera Jember. Legal History of Ethiopia. Hamburg and London: Litverlag. (2000)

Hadiya Zone Educational Department. Landi machcho, Nova publication IFDR Minister of Education. (2006)

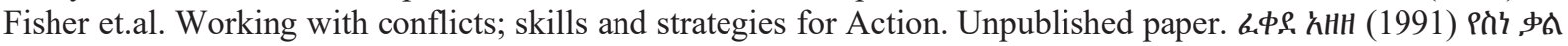

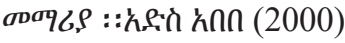

Hadiyyi-Ingilliisis Saga'l Doona. Hadiyyi Minaadaba. Hadiya Zone Education Department. Berhanena Selam Printing. (1996)

Hadiyyi Zoo'n Heechchi Qaanq Awwansa: Yaahoode Hossaana. (2009)

Haile Bubamo: Some notes on traditional Hadiya women. In journals of A.A University. ILO women empowerment: http/www.unfpoorg/gender/empowernment.htm ILO. (1975)

IIRR: the power of landi mecho. Http/www.internet Kenya/Nairobi IIRR (2003)

IPRA Hand book resources and teaching material in conflict resolution, education for human rights, peaces and democracy. Paris (1994)

Jeong H.W: Peace and Conflict studies an introduction USA: - George Mason University. Unpublished paper (2000).

Pankhurst, Alula and Getachew Assafa: Grass roots Justice in Ethiopia, Addis Ababa French center of Ethiopian studies. (2008)

Word haug: Definition of Language. Hadiya Zone Education Department. Berhanena Selam Printing (1994).

Zerhun Asfaw:Yesinatsuf magibiyo A.A Nigd matamiya bet (1996)

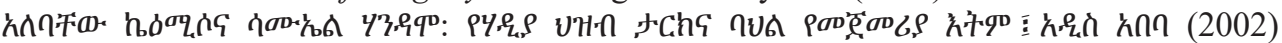

